\title{
ACRL Legislation in 1961
}

By EDMON LOW

$\mathrm{T}$ HE ACRL BOARD of Directors at the Montreal Conference in 1960 voted to promote legislation in the forthcoming session of Congress for federal aid to college and university libraries. There were several reasons for this action, among which were the declining percentage, since the end of World War II, of total institutional incomes being devoted to the libraries; the rapidly rising cost of library materials, especially of serials; the constantly increasing load of available printed materials from presses here and abroad; the greater demands being made on libraries by expanded programs of graduate offerings and by contract research; and the emergence of many junior colleges, in an effort to meet the demand for expanded facilities in the field of higher education, whose libraries were almost nonexistent or greatly in need of encouragement which such aid could give.

As president of ACRL at this time, the writer, under this directive from the board and in cooperation with the Federal Relations Committee and the ALA Washington Office, began to investigate the possibility of such legislation-what was needed, whether it should be a bill by itself or a part of an existing bill, and above all what, in the light of the existing temper of Congress, would stand a reasonable chance of passage. Various leaders in each House were consulted, as well as certain members of committee staffs who are often quite conversant with attitudes of key people in Congress. We were hampered initially by the fact that, when we started work on this, the
Mr. Low is Librarian, Oklahoma State University, and past president of ACRL.

national election had not been held, and so we did not know which party would prevail nor who the chairmen or members of some committees would be.

As a result of this investigation, it seemed best to limit the bill to aid only in acquisition of materials. The Congressmen seemed particularly allergic to assistance for increasing salaries or hiring additional personnel, but almost everybody seemed to be for books. Also it was thought best to make it an amendment to an existing bill rather than to attempt to run the whole gamut with a separate bill. Consequently the draft which is appended was offered as an amendment to the National Defense Education Act, which was up for extension and appeared to offer the best possibility for approval.

The difficulties at first were considerable-the American Council on Education refused to endorse it, saying they could not "fragmentize" their program by supporting legislation for "part" of an institution; the Office of Education could take no stand until a new commissioner was appointed and the wishes of the Administration were known; and it was not in the program or budget submitted by the outgoing Administration. Nevertheless, it came surprisingly close to succeeding. It was approved first by the Senate Subcommittee on Education and later by the full Senate Committee on Labor and Public Welfare, and re- 
ported to the Senate for action. It would almost surely have passed the Senate if it had come to a vote; such vote was delayed pending House action. The House Committee on Education and Labor, after lengthy hearings on the bill and various proposed amendments, transmitted it to the House Rules Committee without recommendation on most of the amendments, including this one, but with the general understanding that in the Conference Committee the amendments approved by the Senate would be accepted by the House. As is now well known, the Rules Committee refused to report the bill for House action and, in a compromise in the closing days of the session, the present Act stripped of all amendments was renewed for two years. The failure of the Rules Committee to report had nothing to do with our amendment-it simply went down in the fierce battling over other issues.

The progress made, which almost resulted in passage, surprised many around Washington and even the ones actively working for it. It usually requires a few years to build up sufficient interest and backing to achieve success-witness the decade of work on the Library Service Act. The credit for this progress was due primarily to the prestige of the American Library Association on the "Hill" and to the tremendous personal popularity of Germaine Krettek, director of the Washington Office, with key members of both houses of Congress. Without this, we could never have gotten off the ground.

Text of the Amendment is appended. It will be noted that it provides for matching grants, that aid is available to all libraries regardless of size, and in both public and private institutions, that a floor is provided (Section 1022) for small libraries so that reasonable grants can be made regardless of past expenditures, and that some help is provided in Section 1022-2-iii which may be used for additional personnel to process added acquisitions. We wish the program could have been larger but it appeared to be the best which could be had under the circumstances. ACRL and the ALA Committee on Legislation are now considering what should be attempted in 1962 and it does appear likely, in the light of the 1961 experience and the generally favorable attitude in Congress toward our program, that some legislation of this kind will be enacted within the next few years.

\section{LIBRARY AMENDMENT TO NDEA}

S.2345 (Report No. 652) a bill to extend and improve the National Defense Education Act of 1958 was favorably reported by the Senate Committee on Labor and Public Welfare on July 31, 1961. Included in the bill is a new Title $\mathrm{X}$, which reads, in part, as follows:

Title $\mathrm{X}$-Strengthening School Library Resources NeEded for TeACHING AND LEARNING

\section{Part C-Library Grants to Institutions of Higher Education} APPROPRIATIONS AUTHORIZED

Sec. 1021. There are hereby authorized to be appropriated $\$ 10,000,000$ for the fiscal year ending June 30,1962 , and for each of the three succeeding fiscal years, to enable the Commissioner to make grants to institutions of higher education to assist and encourage such institutions in the acquisition for library purposes of books (not including textbooks), periodicals, documents, and other related materials (including necessary binding).

\section{Grant Conditions}

Sec. 1022. From the sums appropriated pursuant to section 1021 for any fiscal year, the Commissioner may, upon application therefor, make a grant for the purposes set forth in such section to any institution of higher education-

(1) in an amount not exceeding 25 per centum of the amount expended by such institution during the fiscal year ending June 30,1961 , for books, periodicals, documents, and other related materials (includ- 
ing necessary binding) for library purposes, or not less than-

(A) $\$ 1,000$ if it provides a two-year educational program which is acceptable for full credit toward a bachelor's degree;

(B) $\$ 2,500$ if it provides an educational program for which it awards a bachelor's degree or a more advanced degree; or

(C) $\$ 5,000$ if it provides an educational program for which it awards both bachelors' and advanced degrees; and

(2) if such institution furnishes proof satisfactory to the Commissioner-

(i) that it will expend, during the fiscal year for which the grant is requested, for all library purposes an amount not less than the amount it expended for such purposes during the fiscal year ending June 30, 1961,

(ii) that it will expend, during the fiscal year for which the grant is requested, for library purposes for books, periodicals, documents, and other related materials (including necessary binding) an amount not less than the amount it expended for such materials during the fiscal year ending June 30, 196I, and

(iii) that it will expend for library purposes during the fiscal year for which the grant is requested, in addition to the amount required under clauses (i) and (ii) above, an amount not less than the amount of such grant, and that at least 50 per centum of such expenditure will be for library purposes for books, periodicals, documents, and other related materials (including necessary binding).

\section{Limitation}

Sec. 1023. No grant shall be made under this part for books, periodicals, documents, or other related materials to be used primarily in connection with any part of the program of a divinity school, theological seminary, or other institution, or a department or branch of an institution, whose program is for the education of students to prepare them to become ministers of religion or to enter upon some other religious vocation.

No vote was taken on the bill before adjournment, but action is possible in the 2nd Session (1962).

\section{Workshop on Library Binding}

The RTSD Bookbinding Committee has planned a preconference Workshop on Library Binding to be held at Miami on Saturday, June 16. Three sessions are arranged as follows:

9:30 A.M.-11:30 A.M. "Development of Performance Standards for Library Binding," speakers-Frazer Poole, ALA Library Technology Project; William J. Barrow, W. J. Barrow Research Laboratory; Jean Karl, ALAChildren's Book Council Joint Committee on Binding.

2:00 P.M.-4:00 P.M. A panel discussion on mending, repair and pamphlet binding, with demonstrations of the latest methods and materials.

8:00 P.M.-9:30 P.M. "The Library Binding Situation Today": From a Com- mercial Binder's Viewpoint-Mrs. C. W. Gross, Joseph Ruzicka, Inc.; From a Librarian's Viewpoint-Jerrold Orne, University of North Carolina; From the Viewpoint of a Library Operating its Own BinderyKenneth Allen, University of Washington

There will be exhibits by binders and library suppliers. Advance registration is strongly urged because only 200 participants can be accommodated. The registration fee is $\$ 2.00$. Send your check to Lilly Carter, University of Florida, Gainesville, Florida.

A separate publication, containing the papers presented at the workshop will be edited by Frazer Poole and be sent free of charge to the registrants. 